\title{
KILKA UWAG O ZNACZENIU PARTYTYWNYM DOPEENIACZA W DOKUMENTACH KANCELARYJNYCH XVI WIEKU
}

\author{
SEVERAL NOTES ABOUT THE PARTITIVE GENITIVE IN RUSSIAN \\ ADMINISTRATIVE FILES FROM THE $16^{\mathrm{TH}}$ CENTURY
}

\section{ZOFIA SZWED}

\begin{abstract}
The article deals with the way in which partitive meaning was expressed in genitive constructions in the 16th-century Russian language. It focuses on the problem of codependence between partitive meaning and the genitive inflection $-u$, correlation between the inflections $-a /-u$, and the semantics of nouns which took the inflection $-u$ in the 16th-century administrative files.
\end{abstract}

Zofia Szwed, Uniwersytet im. Adama Mickiewicza w Poznaniu, Poznań - Polska.

Utrwalenie się końcówki - $u$ jako środka wyrażenia znaczenia partytywnego to jeden z najpóźniejszych etapów wielowiekowego procesu kształtowania się dopełniacza liczby pojedynczej rzeczowników rodzaju męskiego w języku rosyjskim. Stabilizacja użycia końcówek $-a /-u$ ma bowiem miejsce $\mathrm{w}$ okresie krystalizowania się norm współczesnego języka rosyjskiego, który przypada na XVIII - początek XIX wieku1. U źródeł ewolucji form dopełniacza tkwi morfologizacja kategorii rodzaju, w wyniku której jeszcze w czasach prasłowiańskich nastąpiła unifikacja odmiany rzeczowników rodzaju męskiego z dawnym tematem na ${ }^{*} \breve{o}$ i na ${ }^{*} \breve{u}$. W rezultacie ujednolicenia poszerzył się zakres użycia końcówki -u, która dotąd była wykładnikiem dopełniacza niewielkiej grupy rzeczowników typu сынъ, медъ. Zasady funkcjonowania fleksji $-u$ w języku epoki staro- i średnioruskiej wyjaśniano różnie. Według Aleksieja A. Szachmatowa końcówka - $u$ szerzyła się wśród tych rzeczowników z tematem na *- ${ }^{*}$, które oznaczały substancję, zbiór przedmiotów, miejsce lub pojęcie abstrakcyjne, np.: оу пэсчана броду (Волынская грамота 1366)². Zdaniem Siergieja P. Obnorskiego końcówkę $-u \mathrm{w}$ pierwszej kolejności przyjmowały wyrazy z ruchomym akcentem³ ${ }^{3}$.

1 П.С. К у з н е ц о в, Историческая грамматика русского языка, Москва 1953, s. 73.

2 А.А. Ш а х м а т о в, Историческая морфология русского языка, Москва 1957, s. 240-243.

${ }^{3}$ С.П. О б н о р с к и й, Именное склонение в современном русском языке. Единственное число, вып. I, Ленинград 1927, s. 166. 
Z kolei Witalij M. Markow uważa, iż fleksja - $u$ występuje przede wszystkim u rzeczowników motywowanych czasownikami, nр.: смотрити всяково запасу к домашнему обиходу (Домострой, с. 38) ${ }^{4}$. Poglądy tych badaczy dotyczą języka staroruskiego oraz języka tekstów XV-XVI w. Nie ma w nich mowy o użyciu końcówki - $u$ dla wyrażenia znaczenia partytywnego. Valentin Kiparski zauważa, że do końca XVII w. funkcjonowanie wariantów fleksji dopełniacza $-a /-u$ nie podlega stałym regułom ${ }^{5}$. W XVIII wieku użycie fleksji $-u$ jest silnie hamowane przez tradycje cerkiewnosłowiańskie. Michaił $W$. Łomonosow wyklucza formy na - $u$ ze sfery wysokiego stylu języka literackiego ${ }^{6}$. Dopiero w pierwszej połowie XIX w. Aleksander Ch. Wostokow stwierdza jednoznacznie, iż końcówka -u służy przede wszystkim do wyrażania znaczenia ilościowego7 ${ }^{7}$. Korelacja znaczenia partytywnego i fleksji -u staje się tak silna, że niektórzy badacze XX w. uznają dopełniacz cząstkowy za samodzielny przypadek obok dopełniacza właściwego ${ }^{8}$. We współczesnym języku rosyjskim szerzej jest uznawana koncepcja sześcioprzypadkowego systemu deklinacyjnego, natomiast użycie partytywne uważa się za jedno ze znaczeń dopełniacza 9 .

Jak już wspomniano, utrwalenie się końcówki - $u$ w roli wykładnika znaczenia partytywnego wśród nieosobowych rzeczowników rodzaju męskiego deklinacji I ma miejsce stosunkowo późno - na przełomie XIX i XX wieku.

4 В.М. М а р к о в, Историческая грамматика русского языка. Именное склонение, Москва 1974, s. 54.

${ }^{5}$ V. K i p a r s k y, Russische historische Grammatik, Bd. II, Heidelberg 1967, s. 259.

${ }^{6}$ М.В. Л о м о н о с о в, Российская грамматика, Санкт-Петербург 1755, s. 81, [online:] http://books.google.ru/books?id=AvlPAAAAcAAJ\&printsec=frontcover\&dq= Lomonosov+1755\&hl=pl\&sa $=X \&$ \&ei $=w$ RPfT4XDEY714QT85KXcCg\&ved=0CDUQ6AEwA $\mathrm{A} \# \mathrm{v}=$ onepage\&q\&f$=$ false [20.06.2012].

Na związek użycia form na - $u$ ze stopniem swobody, z jaką pisarze XVIII-XIX wieku odnosili się do norm języka literackiego, pozostającego pod wpływem tradycji cerkiewnosłowiańskiej, zwraca uwagę również L.A. Bułachowski w pracy: Русский ^итературный язык первой половины ХІХ в., Москва 1954, s. 59-62.

7 A.X. В о с т о к о в, Русская грамматика, Санкт-Петербург 1831, s. 43, [online:] http:/ / books.google.ru/books?id=JDhAAAAAYAAJ\&printsec=frontcover\&hl=pl\#v=on epage\&q\&f=false [20.06.2012].

8 Zwolennikiem rozgraniczenia dwóch dopełniaczy był m.in. Roman Jakobson: R. J a k o b s o n, Морфологические наблюдения над славянским склонением, [w:] Selected writings. II. Word and Language, Hague-Paris 1971, s. 173-174; z kolei Jewgienij V. Klobukow oprócz dopełniacza właściwego i partytywnego wyróżnia również dwa samodzielne przypadki występujące po liczebnikach, tzw. счетный i счетный. Е.В. К л о б у к о в, Семантика падежных форм 8 современном русском литературном языке, Москва 1986, s. 23.

${ }_{9}^{9}$ Andriej A. Zalizniak odrzuca możliwość wydzielenia dopełniacza partytywnego jako przypadka, dowodząc, iż jest on niesamodzielny morfologicznie, a jego użycie jest fakultatywne, zob.: A.А. 3 а л и $з$ н я к, Русское именное словоизменение, Москва 2002, s. $44-45,640$. 
Zapewne formy dopełniacza na - $u$ występowały w użyciu partytywnym dużo wcześniej. Celem niniejszego artykułu jest zbadanie relacji pomiędzy znaczeniem partytywnym i końcówką dopełniacza $-u$ w rosyjskim piśmiennictwie kancelaryjnym XVI w., analiza wariancji fleksji dopełniacza $-a$ i $-u$ w użyciu partytywnym oraz charakterystyka semantyczna rzeczowników występujących z końcówką - $u$ w omawianym znaczeniu przypadka. Materiał językowy zaczerpnięto z 322 dokumentów opublikowanych w zbiorach: Акты Русского государства 1505-1526 гг. і Акты Российского государства ${ }^{10}$. Akta pochodzą z archiwum Troicko-Siergijewskiej Ławry oraz archiwów moskiewskich klasztorów i soborów. Zebrany materiał liczy 86 konstrukcji z dopełniaczem liczby pojedynczej rzeczowników nieosobowych rodzaju męskiego w użyciu partytywnym.

Użyty w znaczeniu partytywnym dopełniacz oznacza pewną całość lub zbiór jednorodnych przedmiotów i może występować:

a) z wyrażeniem, określającym, o jaką konkretnie część tej całości chodzi, lub

b) bez takiego wyrażenia.

W konstrukcjach bez kwantyfikatora to sam dopełniacz określa ilość, zakres pewnej masy objętej czynnością wyrażoną czasownikiem, np.: doлzy заплатити (AP1 251, 1525). Znaczenie partytywne jest wyrażone gramatycznie, poprzez końcówkę. Dopełniacz występuje tutaj w roli dopełnienia bliższego, którą dzieli z biernikiem. Jest to wypadek rekcji podwójnej dopełniacza i biernika przy wtórnym zróżnicowaniu semantycznym, polegającym na tym, że dopełniacz ma znaczenie partytywne, a biernik - całościowe ${ }^{11}$. W podanym przykładzie dopełniacz desygnuje pojęcie abstrakcyjne - doлz. Końcówka -u jako wykładnik dopełniacza oznacza, że czynnością został objęty nie cały obiekt, lecz jego część. W opozycji do wymienionej konstrukcji z dopełniaczem pozostaje wyrażenie: долгъ заплатят (AP1 2, 1505/06), gdzie końcówka zerowa - wykładnik biernika - oznacza czynność ogarniającą cały desygnat biernika. Taką opozycję obserwuje się w rosyjskim języku kancelaryjnym XVI wieku po takich czasownikach jak np.: дати (давати), взяти, платити (заплатити), купити, продати, возити, накинути, сняти, пр.: давати [...] оброку [...] три пуды меду (АР1 29, 1507) - давати им [...] оброк з году на год по книгам (АР1 32, 1507); а взяли есмя, господине, на неи двенатцать рублев да вол пополнбка

10 Акты Русского государства 1505-1526 г2., сост. С.Б. Веселовский. Дополнили и подготовили к печати Р.В. Бахтурина, И.А. Булыгин, Л.И. Ивина, С.М. Каштанов, Л.3. Мильготина, В.Д. Назаров, Л.А. Никитина, Москва 1975 (przykłady zaczerpnięte z tego zbioru oznaczono skrótem AP1); Акты Российского государства, ред. Н.В. Карлов, С.М. Каштанов, М. П. Лукичев, В. Д. Назаров, А.Н. Сахаров, В.Л. Янин, Москва 1998 (materiał pochodzący z tego źródła oznaczono skrótem AP2).

11 A. H e i n z, System przypadkowy języka polskiego, Kraków 1965, s. 92. 
(AP1 4, 1505/06) - вельл есми [...] взяти [...] пополнокъ по купчеи грамоте (AP1 121, 1515).

Dopełniacz partytywny może występować z wyrażeniem, określającym, o jaką konkretnie część danej całości chodzi. Wyrażeniem tym może być:

a) miara wagi, nр.: Велъл есми им давати [...] на свъчи безмънъ воску (AP1 15, 1506);

b) rzeczownik określający ilość, nр.: продал есми [...] треть двора (АР1 24, 1506/07); А мнъ Володимеру досталась [...] половина бору (АР1 164, 1518/19); в Николскои тонь треть невода (АР2 141, 1599);

c) liczebnik główny + nazwa jednostki miary, nр.: возити им еи [...] шесть четвертеи солоду (АР1 179, 1519); Велњл есми им давати [...] пятнатиять четвертеи овса (AР1 15, 1506); возити им еи [...] дватиать четвертеи овса (AP1 179, 1519); давати [...] по двенацати четвертеи овса (АР2 123, 1573/74); свезли: [...] двацать копен овса (AP1 112, 1514); а что у нас [...] пятнацать одонеи и скирдов ржи и овса (AP1 80, 1511);

d) liczebnik główny + nazwa jednostki miary + nazwa substancji, np.: давати [...] оброку [...] три пуды меду (АР1 29, 1507); давати [...] оброку по пятидесять пудовъ соли (АР1 181, 1519/20);

e) liczebnik + nazwa jednostki pieniężnej, nр.: давати [...] оброку [...] noлполтины (AР1 118, 1515); давати [...] оброку [...] по полутора рубля (AP1 282, 1526/27); заплатили княинина ж долгу [...] три рубли (AP1 108, 1513); сняли с меня долгу полчетверта рубля (AР1 1, 1505/06); возмет своего жеребья дватьиать рублев денег (АР1 179, 1519);

f) nazwa przedmiotu lub istoty żywej, nр.: дали есмя [...] пополнбку вол (АР2 101, 1544/45); дал есми пополнбка шубу кунью (АР1 142, 1516/17); дал есми [...] пополнка конь гнъд (АР1 154, 1517/18); Да отослал есми [...] коробью 3 доспъхом, а в коробье доспеху: пять пансыров, да пять шоломов, да наручи шамахииские (АР1 196, 1521/22);

g) określenie miary czasu, nр.: Дати сроку до утрея (AP2 82, 1578); Того ж часу [...] положили крепости (AР2 82, 1578);

h) określenie miejsca, nр.: дала есми [...] свою вотчину селцо Олексино з деревнями вкладу (АР2 82, 1578); пожаловал есми [...] оброком, что $c m b x$ рыбных ловель в нашу казну оброку шло (АР2 130, 1573);

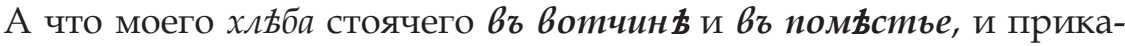
щики мои тот хлњб продадут (АР1 196, ок. 1521/22).

Kwantyfikatory określają ilość z różnym stopniem dokładności. Najbardziej precyzyjne są wyrażenia zawierające liczebnik i nazwę jednostki pieniężnej lub jednostki miary. Mniej dokładne są określniki typu половина, 
mpemı, gdyż wiadomo jedynie, że chodzi o część masy. W konstrukcjach zawierających nazwę przedmiotu lub miejsca, gdzie dla określenia ilości nie używa się żadnej miary, mamy do czynienia z metonimią. Odpowiednia jednostka, miara jest zastąpiona przez przedmiot, który reprezentuje określoną wartość. Z punktu widzenia kwantyfikacji związanej z użyciem dopełniacza nie ma znaczenia, czy ilość czegoś jest określona precyzyjnie, w jednostkach miary, czy metonimicznie, „Liczy się jedynie akt odniesienia tego obiektu do jakiejśs skali wartości w celu określenia stopnia, w jakim uczestniczy on w danym procesie, stanie lub akcji"12.

Jak wspomniano, w konstrukcjach bez kwantyfikatora znaczenie partytywne jest wyrażone gramatycznie - końcówką dopełniacza. W konstrukcjach z kwantyfikatorem głównym wykładnikiem znaczenia partytywnego jest wyrażenie określające ilość. Chodzi tutaj w szczególności o kwantyfikatory zawierające liczebnik i nazwę jednostki pieniężnej lub jednostki miary, a także rzeczownik określający ilość (nр.: безмънъ воску, половина бору, шесть четвертеи солоду, долгу [...] три рубли). Znaczenie partytywne jest tu wyrażone leksykalnie. W dokumentach kancelaryjnych XVI w. dopełniacz cząstkowy występuje przede wszystkim w konstrukcjach z kwantyfikatorem (ponad 90\% analizowanych konstrukcji). Konstrukcje bez kwantyfikatora występują w badanych aktach rzadko. Leksykalny sposób wyrażenia znaczenia partytywnego dominuje nad morfologicznym. Należy zatem stwierdzić, że korelacja znaczenia partytywnego i jego gramatycznego środka wyrażenia - końcówki dopełniacza - dopiero zaczyna się krystalizować. Nie można również mówić o istnieniu współzależności między znaczeniem partytywnym a końcówką - $u$ w języku XVI w. Wniosek ten potwierdzają rezultaty analizy materiału. Rzeczowniki $w$ formie dopełniacza $w$ użyciu partytywnym mogą mieć zarówno końcówkę -u (58\% rzeczowników), jak i końcówkę - $a(42 \%)$. Niektóre rzeczowniki występują z dwoma wariantami fleksji dopełniacza, np.: а дал 40 рублевъ да овцу пополнбка (AP1 4, 1505/05) - дали есмя [...] пополнбку вол рыж (АР2 101, 1544/45); вельль [...] дати срока [...] до утрея (АР2 82, 1578) - велњль дати сроку до утрея (AР2 82, 1578)

Utrwalenie się końcówki - $u$ jako środka wyrażenia znaczenia partytywnego spowodowało zmiany dotyczące semantyki rzeczowników, które mają wariant końcówki dopełniacza $-u$. W analizowanym materiale dopełniacz może wyrażać substancję lub zbiór przedmiotów:

bock, пр.: давати [...] на свъчи безмън воску;

бор, пр.: А мнъ Володимеру досталась [...] половина бору;

доспехи, nр.: Да отослал есми [...] коробью 3 доспъхом, а в коробье досnеху: пять пансыров, да пять шоломов, да наручи шамахииские;

12 B. R u d z k a - O s t y n, Z rozważań nad kategoria przypadka, Kraków 2000, s. 208-209. 
мед, пр.: три пуды меду;

солод, пр.: возити им еи [...] шесть четвертеи солоду.

Dopełniacz może odnosić się również do pojęć abstrakcyjnych, takich jak:

долг, nр.: заплатили княинина ж долгу [...] три рубли;

оброк, пр.: давати [...] оброку [...] три пуды меду;

пополнок, пр.: дал есмя [...] пополнбку вол рыж;

bклад, nр.: дала есми [...] свою вотчину селщо Олексино 3 деревнями

вкладу;

срок, пр.: вельлъ дати сроку до утрея;

час, nр.: Того ж часу [...] положили крепости.

Formy dopełniacza na $-u \mathrm{w}$ użyciu partytywnym odnotowane $\mathrm{w}$ materiale odpowiadają grupom semantycznym rzeczowników z końcówką -u, wyodrębnionym przez Andrieja A. Zalizniaka we współczesnym języku rosyjskim ${ }^{13}$. Zgodnie $\mathrm{z}$ obserwacjami tego badacza formę dopełniacza partytywnego wyrażoną końcówką - $u$ posiada około 370 rzeczowników rodzaju męskiego deklinacji I. W przeważającej liczbie są to wyrazy oznaczające substancję, materiał, rodzaj pożywienia, napoje (w analizowanym materiale np. rzeczowniki: воск, меd, солод). Mniej liczne grupy stanowią rzeczowniki oznaczające niepodzielny zbiór (np. бop), zjawiska fizyczne i pojęcia abstrakcyjne związane z działalnością człowieka (np.: долг, оброк, пополнок, вклаd, срок, чаc). Można zatem wysnuć wniosek, że w języku kancelaryjnym XVI wieku i we współczesnym języku rosyjskim z końcówką - $u$ w użyciu partytywnym występują rzeczowniki o podobnej semantyce. Znacznym zmianom uległy jednak proporcje pomiędzy poszczególnymi grupami semantycznymi. W zebranym materiale odnotowano 5 rzeczowników oznaczających substancję lub zbiór przedmiotów i 6 rzeczowników abstrakcyjnych. W wykazie Zalizniaka rzeczowniki substancjalne stanowią aż 83\% wyrazów z fleksją -u, podczas gdy rzeczowniki abstrakcyjne jedynie 8\%14.

Analiza materiału wykazała, że w języku kancelaryjnym XVI w. znaczenie partytywne jest wyrażane na ogół leksykalnie - przez kwantyfikator, rzadko natomiast morfologicznie - samą końcówką. Korelacja znaczenia partytywnego i jego gramatycznego środka wyrażenia - końcówki dopełniacza $-u$ - dopiero zaczyna się kształtować. Formy dopełniacza na - $u$ tylko nieznacznie przeważają nad formami z końcówką $-a$. W rozpatrywanym materiale dopełniacz w użyciu partytywnym może wyrażać substancję, zbiór przedmiotów lub pojęcie abstrakcyjne. Zakres występowania rzeczowników abstrakcyjnych w języku XVI w. jest znacznie szerszy niż w okresie krystalizowania się norm współczesnego języka rosyjskiego, kiedy końcówka - $u$ staje się środkiem wyrażenia znaczenia partytywnego.

13 А.А. 3 а л и $з$ н я к, op. cit., s. 282-283.

14 Ibidem. 